\title{
形状記憶合金アクチュエータを用いた超小型材料試験機の開発
}

荒井 正行*

\section{Development of Small-Size Material Testing Device Using Shape Memory Alloy Actuator}

by

\author{
Masayuki ARAI *
}

\begin{abstract}
Some electrical appliances, such as mobile phones, have been miniaturized recently to create them in wearable form, because the size of the devices incorporated in those appliances has become remarkably smaller and thinner. For instance, a semiconductor device consisting of a laminated thin-film structure deposited onto a thin substrate by a physical vapor deposition technique is well known. When these laminated devices are designed, the mechanical property of each thinfilm material is required. However, current device design is based on bulk material data. To satisfy the technical requirements, testing devices for measuring the mechanical property of a thin-film material have been developed. The devices become large despite a very small-sized specimen to precisely control the testing waveform. In this study, to achieve more-compact testing devices, a shape memory alloy wire was adopted as a new actuator, and all testing functions of an actuator, load amplification, load cell, and displacement sensor were combined in one unit. For checking the motion of the developed device and the PID control system developed based on an Arduino system, tensile and fatigue tests were conducted for SUS304 thin film. It was confirmed that the tensile and fatigue tests were carried out appropriately according to the control pattern.
\end{abstract}

\section{Key words:}

Small-size material testing device, Shape memory actuator, Thin film, Tensile test, Fatigue test

\section{1 緒言}

近年，パソコンやスマートフォンなどの電子機器は, 小型・高性能化が急速に進められている。これら電子機 器は, 薄膜積層構造体から構成されている。このため, 薄膜積層構造体の設計やその信頼性を保証するために は，薄膜材料そのものの機械的特性をあらかじめ把握し ておく必要がある11.

つぎに火力発電所や原子力発電所などに代表される 大型プラントについて考えてみよう。これら構造物の損 傷状態を把握するために, 構造物から直接 JIS Z2241 に 従った比較的大きな試験片が切り出される ${ }^{2)}$. しかしな がら，運用中の構造物に対してこの様な方法を適用する ことは設備にダメージを与えるため不適切であるとの 指摘もなされている ${ }^{3)}$. このような課題を克服するため に, Arai により構造物の最表面から薄膜状のサンプルを 切り出し，それを材料試験するという新しい損傷診断方 法が提案されている ${ }^{4)}$.この手法が確立されれば，切除 に伴う構造物へのダメージを最低限度に留めることが できる。このため, 大型構造物においても薄膜材料に対 する材料試験技術の確立は重要である.

ところで, これまでの材料試験機では, 油圧, 空気圧, 電気モータが荷重駆動源として用いられてきた ${ }^{5)}$ 。油圧 アクチュエータの特徵として, (1)応答性に優れる, (2)大 きな力を発生できる, という特徴を有する。しかし, 油 圧ポンプなどの大型補器を要するために試験機全体が 大型化する傾向にある. 一方, 空気圧アクチュエータに おいては，油圧アクチュエータに比べて大きな補器を必 要とせずに大きな変位を生み出すことができる.しかし，
空気は密度が低いことから油圧アクチュエータに比べ て応答性にやや劣る。 また, 発生しうる力も小さい. 最 後に電気モータの特徵として, 他のアクチュエータと比 べて試験機の構成をコンパクト化できる点が挙げられ る. しかしながら, モータの比容積 ・質量に対する駆動 力が相対的に低い, 回転運動を直線運動に変換するため の機構を別途準備する必要があるなど問題点もある.

以上に述べたように, 本研究で対象としている試験片 サイズが微小でかつ薄膜状であるため, それに応じて試 験機の小型化も達成されれば, 例えば電子顕微鏡や分析 装置との組み合わせのもと薄膜材の損傷, 破壊メカニズ ムの解明にも資することが期待される. この際, 変位精 度に優れ, 制御上最もコンパクトなアクチュエータを見 出すことが本開発を進める上でのカギといえよう.

これらの背景に鑑みて, Arai は圧電セラミックスをア クチュエータとした小型材料試験機を開発してきた ${ }^{6}$. 圧電セラミックスアクチュエータは, ピエゾ効果により, 電圧を印可することでセラミックスが変形する現象を 利用したものである 7). アクチュエータを駆動するため の特別な補器を必要とせず，ファンクションジェネレー タから発信された電気信号を増幅し, この増幅された電 圧により圧電セラミックスを直接駆動, 制御できる点に 特徴がある. 大きな力を発生できる反面, 発生する変位 が数ミクロンと小さい. このため, 変位をなるべく大き くするために圧電セラミックスを多数積層し, アクチュ エータの全長を長くするなど工夫がなされてきた. ただ し，このような工夫は必然的に材料試験機のコンパクト 化に制約を与えてきた.

$\dagger$ 原稿受理 平成 30年 3月 11日 Received Mar. 11,2018 C2019 The Society of Materials Science, Japan

* 正 会 員 東京理科大学工学部機械工学科 $\bar{\top} 125-8585$ 東京都葛飾区新宿

Department of Mechanical Engineering, Tokyo University of Science, Katsushika-ku, Tokyo, 125-8585. 
このため本研究では，新たなアクチュエータとして形 状記憶合金（SMA: Shape Memory Alloy）ワイヤーに注目 し，これによる材料試験機の開発を試みた. SMA ワイヤ 一は，人工筋肉のために開発されたものであり，大きな たわみを許容し，微弱な印可電圧に対して大きな変位を 発生できる。ただし，発現しうる力は圧電セラミックス のそれに比べて小さい. このため, てこによる増幅機構 と組み合わせることで大きな力が試験片に作用できる ように工夫した。本報告では, 開発した試験機の概要と ステンレス薄膜材 SUS304 鋼を対象に行った引張試験, 疲労試験の結果を示す.

\section{$2 \cdot 1$ 試験機の概要}

\section{2 開発した超小型材料試験機}

本研究では超小型材料試験機を開発するうえでつぎ のような目標を掲げた.

(1) 試験機のサイズを手のひらに載せられるほどの小 型なものにする。

(2) 試験機は, 大掛かりな補器を用いず, ノートブック によりすべての制御とモニタリングを行う。

このような目標を達成するために考案した試験機の 概要図を Fig. 1 に示す. Fig. 1 (a)は試験機の断面図, Fig. 1 (b)は CAD 図を示している。また, Fig. 2 に試作した試 験機の外観を示寸．考案した試験機は，アクチュエータ として SMA ワイヤー, 試験片チャック部 (D部), SMA アクチュエータと試験片チャック部を結びつける弾性 ヒンジ (C 部) とフレーム (A と B 部), からなるシン プルなものである、SMA ワイヤーが収縮することによ り弾性ヒンジを介してフレームが開口するように変形 し, 試験片に引張荷重が作用寸るようになっている. 弾 性ヒンジから SMA ワイヤーまでの距離と弾性ヒンジか ら試験片までの距離の比によりてこの原理により荷重 が増幅される。

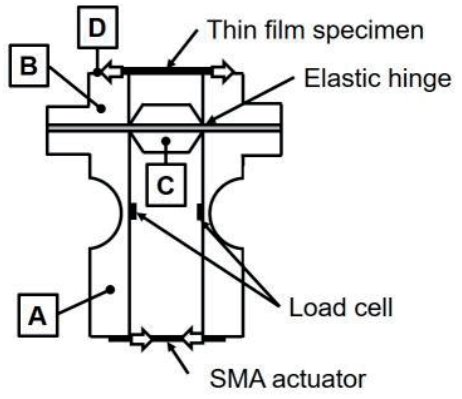

(a)Cross section

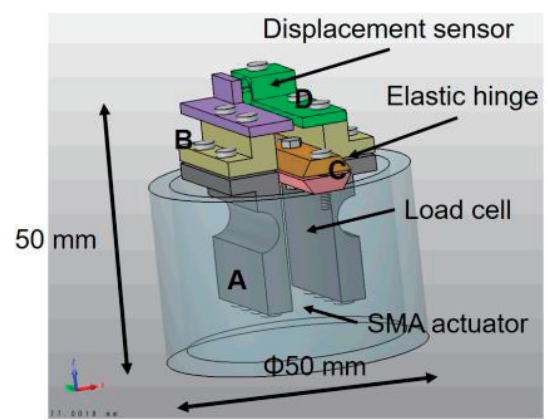

(b)CAD image

Fig. 1 Concept of small-size testing device.

Fig. 3 に試験機の SMA ワイヤー取付部の外観を示す. 図のように SMA ワイヤ両端を端子とネジ，ボルトによ
って固定し，8 本のネジに S の字を描くようワイヤを引 つ掛けた。 また，試験片に生じる荷重はフレームに取り 付けたひずみゲージにより, 変位は渦電流変位センサに より検出した.

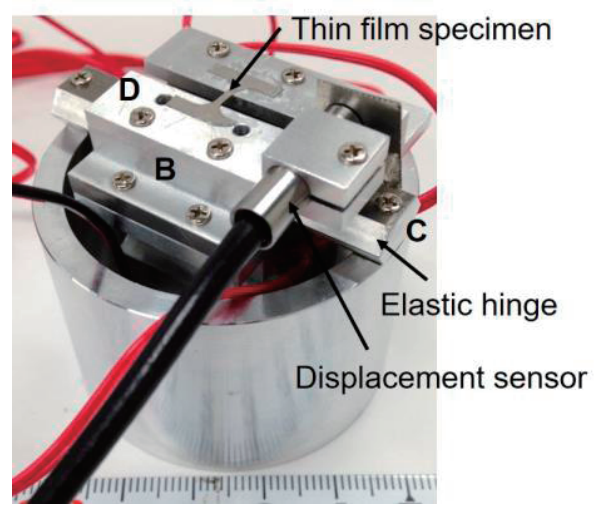

Fig. 2 Small-size testing device developed in this study.

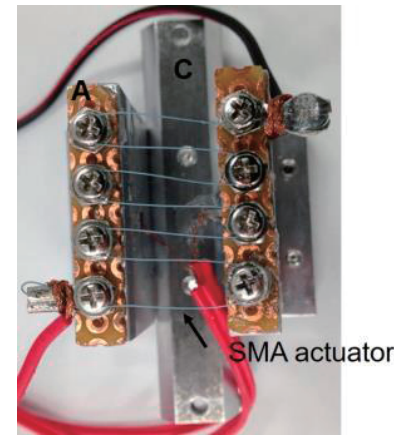

Fig. 3 SMA actuator.

以下に本試験機の動作原理について述べる.

1)外部電源を介して SMA ワイヤーに直流電流を通電し, 発熱させることでアクチュエータを収縮させる。

2)弾性ヒンジ部がフレームの支点となり，アクチュエー タが収縮することで試験部が引張り方向に変位する. この結果, 試験部に取り付けられた試験片には引張力 が働くことになる.

3)フレームにはくびれ加工がなされており，ここにひず みゲージを取り付けることでロードセルの役割をフ レームに持たせる.これにより開発目標であった試験 機の小型化が達成できる.

フレームの材質にはアルミニウム合金を用い, 試験機 の軽量化を図っている。また，弾性ヒンジには $0.1[\mathrm{~mm}]$ 厚さの SUS304 板を用い，適当な復元力を発現できるよ うにしている.

本試験機の特徵をまとめると次のようになる.

・弾性ヒンジを利用することで試験部とアクチュエータ を一体化している点.

・アクチュエータに SMA ワイヤーを用いているために $\mathrm{PC}$ ベースでの制御が可能な点.

・フレームにロードセルの役割を持たせている点.

以上により試験機を手のひらサイズにまで小型化で きるとともに，軽量化することが可能となった。

\section{$2 \cdot 2$ 駆動回路}

開発した試験機を作動させるための駆動回路を Fig. 4 に, 試作した電子回路基板の外観を Fig. 5 に示す. Fig. 4 (a)の試験機の駆動回路の入出力は, Fig. 4 (b)に示す Arduino UNO と呼ばれるマイクロコンピュータとつなが 
っており,これらは USB(Universal Serial Bus)を介して PC とデータ通信を行っている。まず, Arduino の PWM 出 力とデジタル出力は, Fig. 4 (a)の Arduino 用モーターシ ールドと接続されている。 これにより，モーターシール ドに接続されている外部電源から，SMA に対してどの 程度の電圧を負荷するかを操作する。

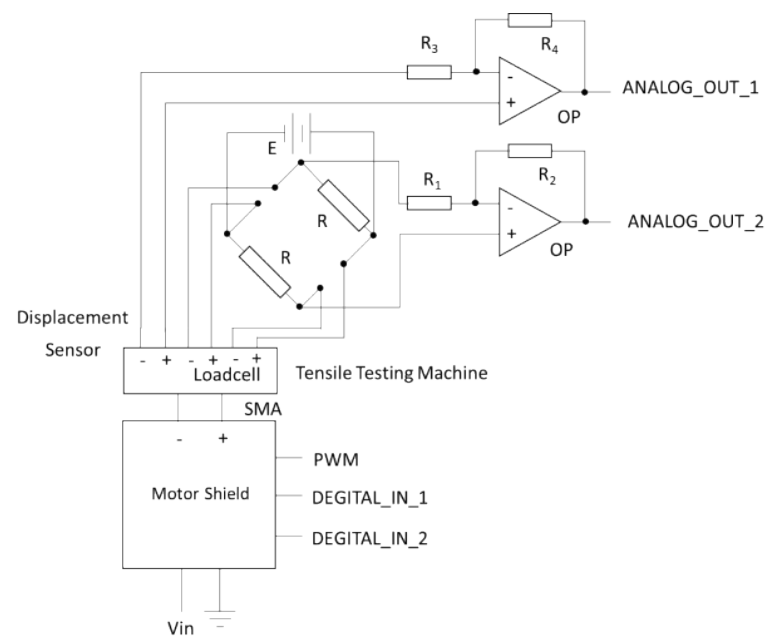

(a)Circuit diagram for testing device

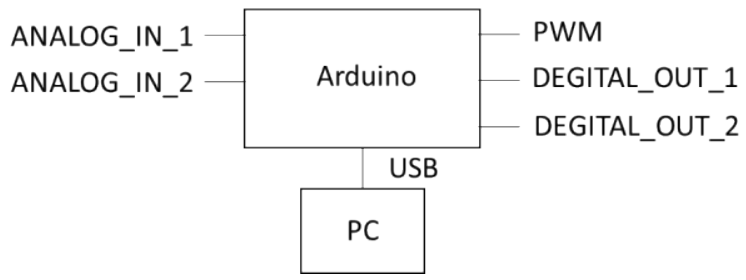

(b)Circuit diagram for Arduino

Fig. 4 Circuit diagrams to control loading pattern.

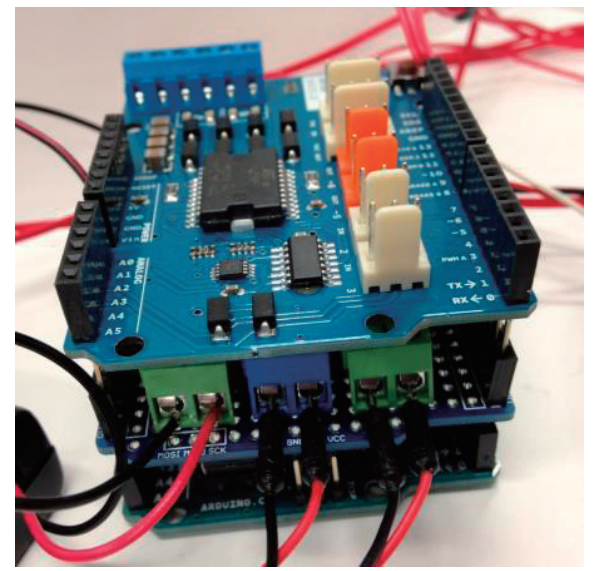

Fig. 5 Appearance of electric circuit board.

アクチュエータとして採用した SMA ワイヤーはトキ コーポレーション製の BMF150 である。本 SMA は，通 電させジュール発熱することによって縮む性質を持つ. Table 1 に SMA ワイヤーの仕様を示す.

ロードセルは，2 ゲージ法によってふたつのフレーム に生じているひずみの大きさを試験片に作用する荷重 に変換するというものである。フレームに接着したひず みゲージ(共和電業, 製品番号 KFG-02-120-C1-11L1M2R) の抵抗を $R_{r}, R_{l}$ とすると, ロードセル出力 $e_{\text {load }}$ は, 入力 電圧 $E$ と次のように関係づけられる。

$$
e_{\text {load }}=\frac{\left(R_{r} R_{l}-R^{2}\right)}{\left(R_{r}+R\right)\left(R_{l}+R\right)} E
$$

試験機が作動するとき，ロードセル部は圧縮されるた め, 負の值の電圧を出力する。しかし, Arduino UNO は 正の值の電圧しか受け取れないので，これを反転する必 要がある，そこで，オペアンプによる反転回路を挿入し た.これにより, 本来のロードセル出力を $e_{\text {load }}$, 反転し た值をV load とすると，以下のような関係となる.

$$
V_{\text {load }}=-\frac{R_{1}}{R_{2}} e_{\text {load }}
$$

また，渦電流変位センサからの出力電圧は非常に小さ く，制御信号として用いるには同電圧信号を増幅する必 要がある。このため，オペアンプによる非反転増幅回路 を組んだ。本来の変位センサ出力を $e_{\text {sensor }}$, 増幅した值 をV $V_{\text {sensor }}$ とすると，

$$
V_{\text {sensor }}=\left(1+\frac{R_{4}}{R_{3}}\right) e_{\text {sensor }}
$$

と表せる，ここで，渦電流変位センサは，キーエンス製 AH-305を使用した. Table 2 に本センサの仕様を示す. また, Table 3 に駆動回路に必要な供給電源ならびに電気 信号の増幅のために用いた抵抗值 $R, R_{i}(i=1, \ldots, 4)$ をま とめたものを示す.

Table 1 Specification of SMA wire (BMF150).

\begin{tabular}{|c|c|}
\hline Standard diameter [mm] & $\varphi 0.15$ \\
\hline Maximum generated load [N] & 1.47 \\
\hline Maximum strain [\%] & 4.0 \\
\hline Fatigue life [cycle] & 1000000 \\
\hline Standard drive current [mA] & 340 \\
\hline Standard drive voltage [V/m] & 20.7 \\
\hline Standard resistance $[\Omega]$ & 61 \\
\hline
\end{tabular}

Table 2 Specification of displacement sensor (AH-305).

\begin{tabular}{|c|c|}
\hline Standard diameter [mm] & $\varphi 5.4$ \\
\hline Measuring range [mm] & $0 \sim 1$ \\
\hline Output voltage [V] & $0-1$ \\
\hline Impedance [ $\Omega]$ & 100 \\
\hline Resolution [\%] & 0.1 of F.S. \\
\hline Linearity [\%] & \pm 1 of F.S. \\
\hline Sensor head weight [g] & 45 \\
\hline
\end{tabular}

Table3 Value of resistance and supply voltage.

\begin{tabular}{|c|c|}
\hline Name & Value and model number \\
\hline \hline Vin & DC12[V] \\
\hline $\mathrm{E}$ & $\mathrm{AC} 100[\mathrm{~V}]$ \\
\hline $\mathrm{R}$ & $\begin{array}{r}\text { Depending on dynamic strain } \\
\text { meter: AS1103(KYOWA) }\end{array}$ \\
\hline $\mathrm{R}_{1}$ & $10[\mathrm{k} \Omega]$ \\
\hline $\mathrm{R}_{2}$ & $10[\mathrm{k} \Omega]$ \\
\hline $\mathrm{R}_{3}$ & $1[\mathrm{k} \Omega]$ \\
\hline $\mathrm{R}_{4}$ & $22[\mathrm{k} \Omega]$ \\
\hline OP & $\mathrm{LM} 358 \mathrm{~N}$ \\
\hline SMA & BMF150(TOKI CORPORATION) \\
\hline $\begin{array}{c}\text { Displacement } \\
\text { Sensor }\end{array}$ & $\begin{array}{r}\text { Sensor:AH-305,Amp:AS-440- } \\
01(\mathrm{KEYENCE})\end{array}$ \\
\hline Motor Shield & Arduino Motor Shield \\
\hline
\end{tabular}

これら $V_{\text {load }}, V_{\text {sensor }}$ は, Arduino にアナログ信号として 入力され, USB 接続された PC にそれらの值が表示され 
る。また，荷重制御の場合は $V_{\text {load }}$, 変位制御の場合は $V_{\text {sensor }}$ の值を用いて, Fig. 6 に示す PID 制御を行う.

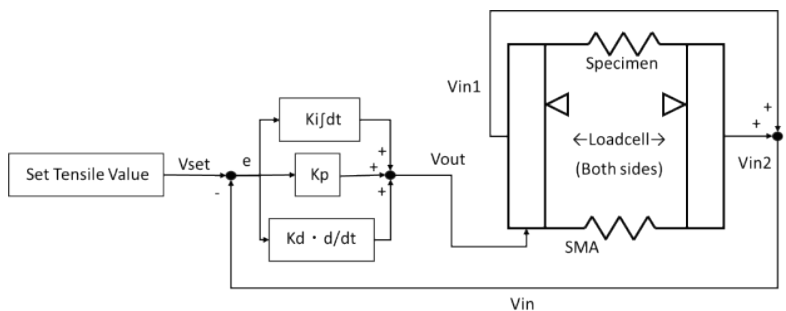

Fig. 6 PID control diagram.

\section{$2 \cdot 3$ ロードセルの較正}

本節では，試験機に組み込んだロードセルの較正を行 った結果を示す。

試験片に生じた試験力はつぎのようにして測定した。 厚さ $10[\mu \mathrm{m}]$, 幅 $5[\mathrm{~mm}]$ の SUS304 フィルム(ニラコ社製) の中央にひずみゲージ(共和電業, 製品番号 KFG-02-120C1-11L1M2R)を貼り，これを試験機チャック部に瞬間接 着剂で固定した。試験力 $F[\mathrm{~N}]$ は，ひずみゲージの出力に 弾性係数を乗じることで簡単に求められる.

本試験機においては，フレームにおけるくびれ部と反 対側の平滑面にひずみゲージ(共和電業、製品番号 KFG02-120-C1-11L1M2R)を接着し，これをロードセルとした。

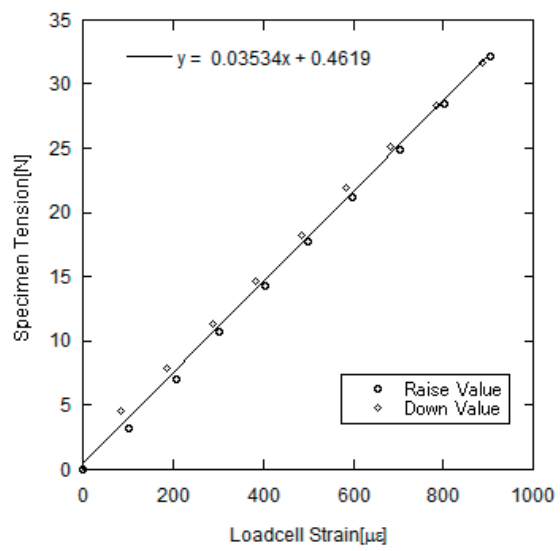

Fig. 7 Relationship between testing load and load cell strain.

試験力とロードセル部におけるひずみ值の関係を調 ベるために，ロードセル部に装着したひずみゲージの出 力を $\mathrm{PID}$ 制御の制御值とし，フィルム中央部に接着した ひずみゲージによる試験力と比較した．Fig. 7 に試験結 果を示す. 図中の Raise Value はロードセル部ひずみ上昇 時の值, Down Value はロードセル部ひずみ減少時の值で ある。この測定結果から，上昇時ならびに減少時ともに 試験片での試験力とロードセル部でのひずみの間には 比例関係が成立していることが確認できる。ただし，試 験力が低いレベルにて $1.5[\%] / \mathrm{FS}$ 程度の誤差が生じてい た。これは $2 \cdot 1$ 節で説明したように SMA ワイヤーをボ ルトに巻き付けることでアクチュエータを作製してい る.このため, 試験力の増加, 減少時にワイヤーとボル 卜の接触状態が微視的に変化したためにこのような誤 差が生じたものと考えられた。

本研究では, Fig. 7 の結果に基づいて以下をロードセ ルの較正式とすることとした。

$$
F_{S}=0.03534 \varepsilon_{L}+0.4619
$$

$$
\left(0 \leq F_{S} \leq 30[N]\right)
$$

\section{$2 \cdot 4$ 周波数-最大振幅特性}

SMA ワイヤーをアクチュエータとした本試験機によ り疲労試験を行う際には，あらかじめアクチュエータの 動特性を把握しておく必要がある。このため，本試験機 の周波数と最大変位振幅の関係(以下, 周波数一最大振幅 特性と呼ぶ)を明らかにしておく. 周波数一最大振幅特性 とは，試験機チャック部に試験片が装着されていない， 無負荷状態において，アクチュエータに最大駆動電圧を ある周波数で繰返し印可した際に，試験片チャック部で 生じた最大変位振幅量がどのように変化するのか調心゙ たものである.

本試験においては, 試験片チャック部に装着した渦電 流変位センサ(キーエンス社, 製品番号 AH-305)による変 位值を制御值としてPID 制御を行う。制御波形は三角波 形とした。このようにして得られた周波数一振幅特性を Fig. 8 に示寸. 周波数が $0.1[\mathrm{~Hz}]$ 以下では，最大振幅は 0.15 0.16[mm]程度となった. これは本試験機の機構上最 大の変位量にほぼ一致する。これに対して周波数が高く なり，2[Hz]になると最大変位振幅量は $0.04[\mathrm{~mm}]$ 程度ま で低下する.よって，この周波数以上になると疲労試験 が行えないことがわかった。このように高周波数領域で 疲労試験が行えなかった理由として SMA ワイヤーに生 じた発熱が原因と考えられる。低周波数では，アクチュ エータ駆動のために発熱した SMA ワイヤーが泠却され るまでに十分な時間があった。しかし，次第に周波数が 高くなるにつれて SMA ワイヤーを冷却するための時間 を十分にとることができなくなる。

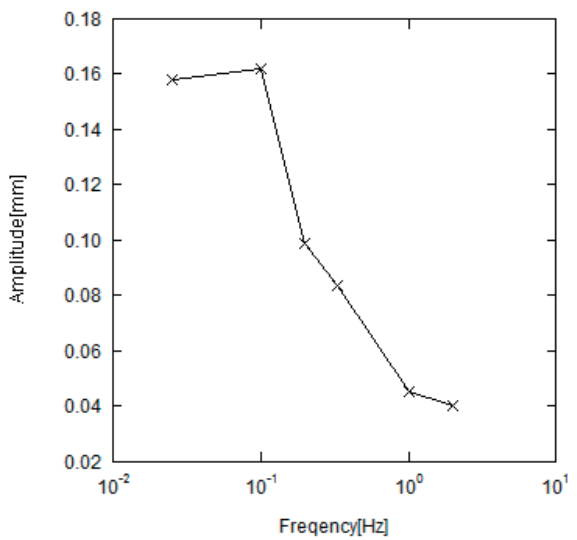

Fig. 8 Relationship between amplitude and frequency.

\section{$2 \cdot 5$ 超小型材料試験機のスペック}

以上の試験結果に基づき本研究で開発した超小型材 料試験機のスペックをまとめると Table 4 のようになる.

Table 4 Specification of small-size testing device.

\begin{tabular}{|c|c|}
\hline Max tensile testing load & $30[\mathrm{~N}]$ \\
\hline Min tensile testing load & $0[\mathrm{~N}]$ \\
\hline Max frequency & $2[\mathrm{~Hz}]$ \\
\hline Max amplitude & $0.16[\mathrm{~mm}]$ \\
\hline Min amplitude & $0[\mathrm{~mm}]$ \\
\hline Disp. resolution & $0.1[\%] / \mathrm{FS}$ \\
\hline
\end{tabular}

\section{SUS304鋼薄膜材の引張・痕労試験 $3 \cdot 1$ 供試材ならびに試験方法}

本研究で開発した試験機を用いて, 薄膜材の引張試験 および疲労試験を行った。本試験に供した材料はオース テナイト系ステンレス鋼(SUS304)であり，圧延された平 板素材から放電加工により所定の形状となるよう加工 
した。試験片の形状を Fig. 9 に示す。マイクロメータの

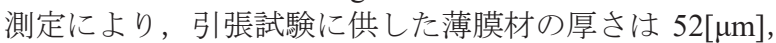
疲労試験のそれは $54[\mu \mathrm{m}]$ であった.

これらの試験片を, 試験機チャック部に瞬間接着剤(東 亞合成, アロンアルファ)で接着した。 引張, 疲労試験と もに荷重制御により試験を行った。 引張試験では負荷速 度 $0.6[\mathrm{~N} / \mathrm{s}]$ で試験時間を 50 秒, 疲労試験では周波数を $0.1[\mathrm{~Hz}]$ とした.

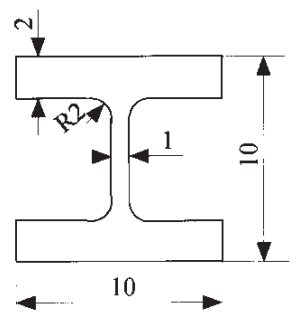

Fig. 9 Thin film specimen geometry.

\section{$3 \cdot 2$ 引張試験結果}

Fig. 10 に本薄膜試験片の応力一変位線図を示寸. 図よ り，変位とともにほぼ線形に応力が増加するとともに， 降伏応力に達した後, 変位とともにゆるやかに応力が増 加するようになる。 寸なわち，ステンレス鋼に見られる 典型的な応力一変位曲線である。ここで，本線図におい て変位のゼロ点がやや外れているが，実際に測定された 応力一変位線図においては変位とともに応力が緩やか に増加したことによる.この非線形挙動を除去したため 図のようにゼロ点がやや外れたように示されている。こ のような非線形挙動を示した理由は試験機の構造によ る。すなわち，開発した試験機においては弾性ヒンジを 介して試験側とアクチュエータ側をフレームで接合さ せている．これに加えてアクチュエータ部で SMA ワイ ヤーをフレームに設置したボルトに引つ掛けるような 構造となっている。 このため, 弾性ヒンジの非可逆性挙 動, ワイヤーとボルトの接触状態が影響し, ワイヤー収 縮とともに小さな試験力レベルではワイヤーとボルト の接触ならびに弾性ヒンジの変形が関与して変位とと もに応力がやや非線形に増加したと考えられる。なお, 周知のように一般の材料試験機においてもクロスヘッ ド変位と荷重の間において荷重レベルが小さい領域で は非線形性が認められる。このため, 今後試験片に生じ ているひずみを検出することでこのような問題は解消 できるものと考えられる。

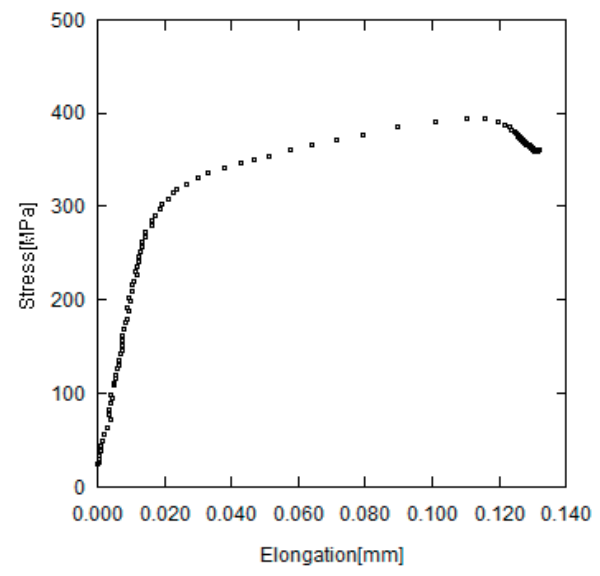

Fig. 10 Stress-displacement diagram for SUS 304 thin film specimen with thickness of $52[\mu \mathrm{m}]$.
結果は省略するが，バルク材の引張試験によれば伏応 力は $180[\mathrm{MPa}]$ であった. これに対して本応力一変位曲線

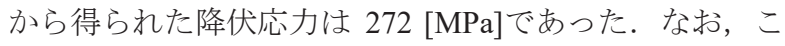
こで言う降伏応力は， $0.2 \%$ 耐力の定義とは異なり, 同線 図における直線から外れた点での応力を降伏応力と定 義した. このように定義された降伏応力においてもバル ク材のそれに比べて高い。このことから, 化学成分が同 一であっても薄膜材はバルク材に比べ降伏応力が高い ことがわかった．なお，これまでにも同様の傾向が指摘 されている ${ }^{8)}$. 引張応力が降伏応力に近づくと, 薄膜厚 さ方向に転位が活発に移動するようになる。しかし，こ の転位の移動は薄膜表面に近づくと固着して動きにく くなり，このために降伏応力が上昇するとの物理的メ力 ニズムが提案されている.

\section{$3 \cdot 3$ 疲労試験結果}

試験波形を Fig. 11 に示す。図より，荷重制御に基づく 疲労試験が適切に行われていることが確認できる.

繰返し数 $n$ が $1 ， 5 ， 10$ のときの応力一変位線図を Fig. 12 に示す. 繰返し数 $n=1$ にて変位に比例して忍力 が増加し，降伏点に達すると変位に伴う応力の増加がゆ るやかになり試験片は塑性変形をする。除荷時には, 弾 性変形時と同じ傾きで応力が減少し, 無負荷になると永 久変形が生じる. その後, 再負荷時に除荷時に描いた線 図に沿って変位とともに応力が増加する, いわゆるシェ イクダウン現象が認められる. 結局, 本疲労試験を 4200 サイクルまで行ったが, 疲労寿命には至らなかったため, 途中で試験を止めた.

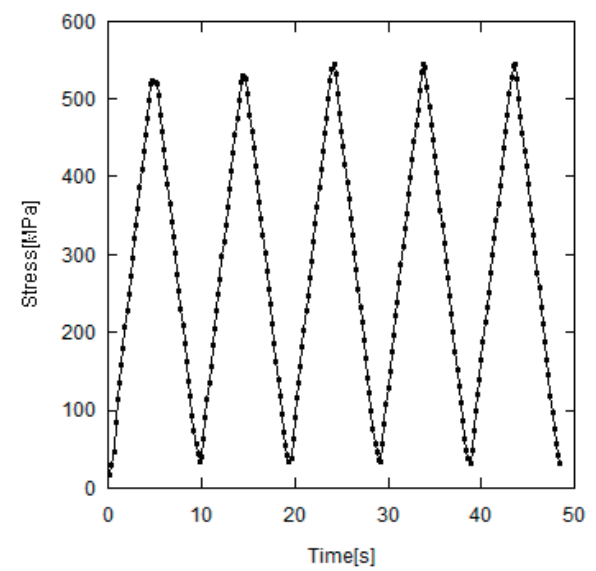

Fig. 11 Stress wave form controlled by PID.

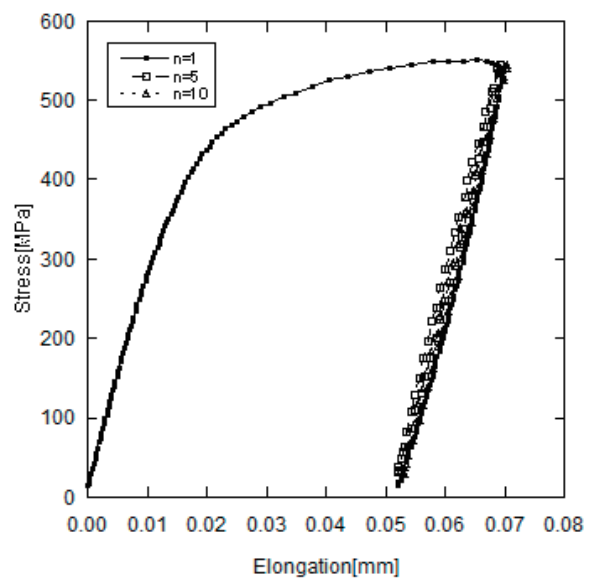

Fig. 12 Stress-displacement curve in cyclic loading. 


\section{4 結}

本研究では，薄膜・微小材料の機械的特性を測定する ことが可能な超小型材料試験機の開発を行った. 材料試 験機の超小型化のために, 新たなアクチュエータとして 形状記憶ワイヤーに注目した。ただし，形状記憶ワイヤ 一は，人工筋肉のために開発されたものであり，大きな たわみを許容し, 微弱な印可電圧に対して大きな変位を 発生できる．ただし，これまでのアクチュエータに比べ て発現しうる力は小さい。このため，てこによる増幅機 構をコンパクトな構造のもとに実現するため, 弾性ヒン ジを介して長さが異なるフレームを配置し，その両端に 試験片固定部とアクチュエータを設置した。これにより 手のひらサイズにまで試験機の大きさを小さくするこ とに成功した，ステンレス薄膜材 SUS304 鋼を対象に引 張試験, 疲労試験を行い, 開発した試験機が適切に動作 していることを示した。

\section{参 考 文 献}

1) F. M. Mwema, O. P. Oladijio, S. A. Akinlabi, E. T. AkinlabiK. Ohnishi and S. Matsuda, "Properties of physically deposited thin aluminum film: a review", Journal of Alloys and Compounds, Vol.747, No.30, pp.306-323 (2018).

2) A. Garzillo, C. Guardamgna, L. Moscotti and L. Ranzani, "A technique for the residual life assessment of high temperature components based on creep-rupture tests on welded miniature specimens", International Journal of Pressure Vessels and Piping, Vol. 66, Issue 1-3, pp.223-232 (1996).

3) R. Viswnathan, "Residual life technique for plant life extension", Material Science and Engineering: A, Vol. 103, Vo. 1, pp.131-139 (1988).

4) M. Arai, "Development of in-situ high-temperature small fatigue testing device by SEM", Kikai No Kenkyu, Vol.59, No.3, pp.353-361 (2007).

5) M. Arai, "Toward an unknown filed in material testing device in future", TEST, Vol.14, pp.28-29 (2010).

6) M. Arai and T. Ogata, "Development of small fatigue testing machine for thin film", Transactions of the Japan Society of Mechanical Engineers, Series. A, Vol.68, No.669, pp.801-806 (2002).

7) K. Motoo, N. Toda, F. Arai, T. Fukuda, T. Matsuno, K. Kikuta and S-I. Hirano, "Tailor-made multilayer piezoelectric actuator having large displacements and forces", Transactions of the Japan Society of Mechanical Engineers, Series. C, Vol.72, No.722, pp.33023308(2006).

8) C. Zhou and R. LeSar, "Dislocation dynamics simulations of plasticity in polycrystalline thin film", International Journal of Plasticity, Vol.30-31, pp.185201 (2012).

9) H. Waki, K. Takizawa, M. Kato and S. Takahashi, "Accuracy of Young's modulus of thermal barrier coating layer determined by bending resonance of a multilayered specimen", Journal of Thermal Spray Technology, Vol.25, Issue 4, pp.684-693 (2016). 